\title{
GENDERING THE ISLAMIC JUDICIARY: Female Judges in the Religious Courts of Indonesia
}

\section{Euis Nurlaelawati}

Sunan Kalijaga State Islamic University, Yogyakarta, Indonesia

\section{Arskal Salim}

University of Western Sydney, Australia

\section{Abstract}

Compared to other Muslim countries, Indonesia has been the forefront, if not the frontrunner, in welcoming women to occupy a position as judges at the Islamic court. Despite few Indonesian women were already sitting at Islamic courtrooms and hearing cases on family law issues as early as in 1960s, it was only in 1989 that Indonesia fully accommodated female judges at the religious courts. From this onwards, female judges were recruited more than ever and began accessing a number of rights and positions like their male counterparts. This paper discusses female judge and women litigants at Islamic courts of Indonesia. This paper not only discusses the way in which women were recruited to be judges at the Indonesian Islamic courts, but also explores some factors leading Indonesian women to engage in the judicial practice. In addition, this paper looks at the way in which female judges exercise their authority to protect rights of disadvantaged women litigants. This paper argues that despite female judges have the same skills in interpreting law as their male colleagues do and that they have to some extent better gender sensitivity, they unfortunately bave not maximised utilising these legal skills for the benefits of women litigants.

[Dibandingkan dengan negara-negara Islam lainnya, Indonesia telah menjadi garda depan -jika tidak disebut pelopor-dalam mengangkat perempuan sebagai hakim di Pengadilan Agama. Meskipada decade 1960-an sejumlah 
perempuan sudah menduduki jabatan hakim dan telab menyidangkan kasuskasus keluarga di Pengadilan Agama, hanya pada tabun 1989 pengangkatan perempuan pada Pengadilan Agama ditegaskan secara formal dan legaal oleh pemerintah Indonesia. Sejak saat itu, jumlah hakim perempuan di pengadilan agama meningkat dan mereka memiliki kesemepatan untuk memperoleh hak dan posisi penting di Pengadilan Agama, sejajar dengan hakim laki-laki. Artikel ini mendiskusikan keterlibatan perempuan, baik sebagai hakim maupun pibak yang berperkara, di Pengadilan Agama. Tidak hanya menjelaskan bagaimana perempuan direkrut sebagai hakim di Pengadilan Agama, artikel ini juga mengulas faktor-faktor penting yang mendorong keterlibatan perempuan dalam prak.tek peradilan. Selain itu, juga dijelaskan peran hakim perempuan dalam melindungi hak para perempuan yang berperkara di pengadilan. Penulis berkesimpulan bahwa meski para hakim perempuan memiliki kompetensi yang sama dalam memutus perkara seperti para bakim laki-laki dan dalam batas tertentu memiliki sensitifitas gender yang lebih kuat ketimbang laki-laki, peran mereka masib terlibat belum maksimal, terutama dalam memberikan perlindungan terbadap pemenuban hak-bak perempuan.]

Keywords: Islamic Judiciary, female judges, and legal notion

DOI: 10.14421/ajis.2013.512.247-278

\section{A. Introduction}

As stipulated in many classical Islamic jurisprudence textbooks, a judge is required to be a mature Muslim male. ${ }^{1}$ Deviation from this rule was rare and scarcely ever happened in numerous Muslim countries. In Indonesia, where the Shafici legal jurisprudence has been prevalent for centuries, the initial appointment of female judges to the Islamic courts in particular was an uneasy process. As early as the 1960s, the Ministry of Religion and the Directorate of Religious Justice, whose main responsibility was to oversee the Islamic courts, sought to overcome this issue and enhance the quality of Islamic judges. In particular, they provided the Islamic judges with specific training on technical matters

\footnotetext{
${ }^{1}$ Ibn Qudama, Al-Mughni (Egypt: Dār al-Manār, 1967), pp. 39-41.
} 
that would increase their expertise to the standard of civil judges. ${ }^{2}$ The Directorate of Religious Justice not only appointed young male graduates of the Islamic university to replace older Islamic judges who had no recognized academic degree and lacked required judiciary skills, it also recruited women as members of Islamic courts.

Compared to other Muslim countries, Indonesia was at the forefront, perhaps even the frontrunner, in welcoming women to occupy a position as judges in courts in general and the Islamic court in particular. Nevertheless, despite the fact that as the early as the 1960s a few Indonesian women were already sitting in Islamic courtrooms, hearing cases on family law issues and economic cases over which since 2006 religious courts have had jurisdiction, it was only in 1989 that Indonesia fully accommodated female judges in the religious courts. From 1989 onwards, female judges were recruited in increasing numbers, accessing a number of rights and positions equivalent to those of their male counterparts. While some were promoted to work for the appeal courts at provincial levels, others were offered top positions to manage municipal or district religious courts in particular regions of Indonesia. The Islamic courts of Lamongan and Madiun in East Java, for examples, are now chaired by female judges. ${ }^{3}$ In spite of this, there are still fewer female judges than male ones. It must be acknowledged, however, that female judges have the same skills in interpreting the law as their male colleagues.

This paper points out that in general, Indonesia poses no serious challenge to the appointment of female judges to the civil courts. The position of female judges in Islamic courts is therefore worth discussing, mostly because resistance to their appointment was initially quite fierce. In contrast, the appointment of women as judges in the general judicature did not encounter a similar degree of opposition, probably because, dating back to the early days of Indonesia's independence, Muslim leaders were prone to pay attention mostly to Islamic institutions established by the state, while other legal institutions were considered to be parts of the

${ }^{2}$ Daniel S. Lev, Islamic Court in Indonesia: A Study in the Political Bases of Legal Institution (Berkeley: University of California Press, 1972), p. 106.

${ }^{3}$ Hermansyah, "Hakim Perempuan di Peradilan Agama, Riwayatmu Kini," http:/ /badilag.net/component/content/article/315-berita-kegiatan/10712-hakimperempuan-di-peradilan-agama-riwayatmu-kini-234.html, accessed on 23 April 2012. 
secular state of Indonesia, so there were very few, if any, criticisms from the Islamic point of view.

The presence of female judges in Indonesian religious courts not only boosts women's engagement in public sector jobs, but also results in improving access to justice for disadvantaged female litigants, especially in family matters. ${ }^{4}$ This paper discusses the way women were appointed to the position of judges in the Indonesian Islamic courts and explores some factors that lead Indonesian women to engage in the judicial practice in the first place. This paper looks at the way female judges exercise their authority to protect the rights of disadvantaged female litigants. In our discussion of the way they defend women's interests in their decisions, we argue that, for one reason or another, female judges in religious courts have unfortunately not utilized their legal skills to the maximum benefit of female litigants.

After discussing the structural changes that occurred within the Islamic judiciary of Indonesia, the following section describes the profile and development of Indonesia's Islamic judiciary over the past three decades. A brief, general profile of the Islamic court is offered, particularly its institutional developments, including the transfer of management from the Ministry of Religious Affairs to the Supreme Court in 1999. A discussion of the gender composition of Indonesia's Islamic judiciary is then presented, specifically looking at female judges, their number, and their positions in Indonesia's religious courts system. Finally, before giving our conclusions, the paper provides a number of cases to investigate gender notions as found in decisions made by female judges in religious courts.

\section{B. Islamic Judiciary of Indonesia}

Islamic judiciary is one of the domains of Indonesian judiciary and the following is the discussion on the historical accounts of Indonesian court system. It will focus on two important aspects: the management and adminsitration of Islamic court and the recruitment process of its judges in general.

${ }^{4}$ See for instance, Arskal Salim et. al., Demi Keadilan dan Kesetaraan: Dokumentasi Program Sensitivitas Gender Hakim Agama (Jakarta: PUSKUMHAM UIN Jakarta, 2009). 


\section{Administration and Management}

Since its inception, the Islamic court of Indonesia has experienced dynamic developments. Formally established in the colonial period as a priesterraad, the Islamic court system has developed over time in terms of its institutions, laws, and human resources. ${ }^{5}$ Authority over the courts has shifted over the years. During the colonial period, Islamic legal institutions fell under the administrative purview of the Ministry of Justice. After achieving independence in 1945, the Indonesian government formed the Ministry of Religious Affairs and addressed the matter of authority over the Islamic courts in its first official act. ${ }^{6}$ Under the Ministry of Religious Affairs, the Islamic court of Indonesia was supervised for several decades by the Directorate of Development of Religious Justice (Direktorat Pembinaan Badan Peradilan Agama/Ditbinbapera). Despite the many challenges it encountered from time to time, the court survives today and has even become stronger, now having the status of an official state court, as stipulated in Law 14 of 1970 of the Basic Act on Indonesian Judiciary.

This Law further introduced significant changes in both the institutional and juridical supervision of the Islamic courts. Article 10 of the Act establishes that judicial power is to be exercised by four types of courts: general courts, Islamic courts, military courts, and administrative courts. ${ }^{7}$ It was stated further that the Supreme Court is the highest judicial authority in the country and, as such, has the power to review decisions from the highest appellate authority within all four systems. The management and administration of the Islamic court was further regulated in 1989 when the Religious Judicature Act was issued, which assigned administrative responsibility for the Islamic courts to the Ministry of Religion, and responsibility for "technical juridical matters" to the Supreme Court. ${ }^{8}$

${ }^{5}$ For the best account on this issue, see for instance, Daniel S. Lev, Islamic Court, Mark E. Cammack, "The Indonesian Islamic Judiciary," in Mark E. Cammack and Michael Feener (eds.), Islamic Law in Contemporary Indonesia: Ideas and Institutions (Massachuset: Harvard University Press, 2007), pp. 146-169; Mark E. Cammack and Michael Feener, "The Islamic Legal System in Indonesia," Pacific Rim Law and Policy Journal, vol. 21, 1, 2012, pp. 13-42.

${ }^{6}$ Daniel S. Lev, Islamic Court, pp. 41-42. See also M.B. Hooker, Islamic Law in South-East Asia (Kuala Lumpur: Oxford University Press 1984), p. 255.

${ }^{7}$ See Basic Act on Judicial Power (No. 14 /1970).

${ }^{8}$ See Religious Judicature Act No. 7/1989. 
This division of responsibility ended in 2004 as a result of a more general package of judicial reforms introduced following the resignation of President Suharto. In 1999 the government issued a 1999 amendment to the 1970 Basic Act on Judicial Power, which established a 'one roof" system of judicial administration. This Amendment aims to transfer administrative, structural, and financial authority over all four branches of the Indonesian judiciary to the Supreme Court. ${ }^{9}$ The Ministry of Religion, which was initially reluctant to implement the rule to place the Islamic courts under the authority of the Supreme Court, finally transferred the administration, structure, and finances of the Islamic courts from its own auspices to the Supreme Court in 2004. ${ }^{10}$ The Bureau of Islamic Courts (Badan Peradilan Agama/Badilag), the office within the Supreme Court that supervises the Islamic judiciary, adopted and recruited most of the personnel from the Directorate of Development of Religious Justice. The Ministry of Religious Affairs then eliminated this directorate from its structure.

\section{Recruitment and Number of Judges}

In Indonesia, a judge is recruited under the civil law system, where the judiciary is a separate career path in the system. Judges are therefore selected from new law graduates, typically devoting their entire career to judicial service. ${ }^{11}$ Each year a circular is issued announcing the recruitment plans for the coming year and inviting applications. ${ }^{12}$ University graduates with degrees in either Islamic or civil law who are interested in serving as religious judges are requested to submit an application letter, statement of interest, and a variety of mandatory personal documents. ${ }^{13}$ Applicants who meet certain qualifications specified in the Law on the Religious

${ }^{9}$ Ahmad Mujahidin, Peradilan Satu Atap di Indonesia (Jakarta: Refika Aditama, 2007), p. 91.

${ }^{10}$ Ibid., p. 99.

${ }^{11}$ Euis Nurlaelawati and Abdurrahman Rahim, "The Training, Appointment and Supervision of Islamic Judges in Indonesia," Pacific Rim Law and Policy Journal, Vol. 21, 1, 2012, p. 50 .

${ }^{12}$ Ibid.

${ }^{13}$ For the detailed of the documents to be attached, see "Badan Peradilan Agama/ The Islamic Court Division of the Supreme Court,” at http://www.badilag. net/. 
Judicature ${ }^{14}$ must pass a number of examinations to become officially appointed as a judge. The examination process is conducted in two sessions. ${ }^{15}$

The number of Islamic courts and judges has increased significantly in the past decade. According to the data released in 2009 by the Badilag of Supreme Court, the number of first-instance Islamic courts in Indonesia was 343 district court offices with 29 appellate court offices. ${ }^{16}$ While the number of appellate courts remained unchanged until 2012, the number of first-instance courts increased in three years to 359 district court offices.

Each court office houses a chairman, a vice-chairman, six to eight judges, a clerk, and a dozen administrative supporting staff. The number can change in some district court offices and is not constant over time. From 2004 to 2006, the number of judges in some district courts fluctuated between nine and ten, including the chairman and the vice-chairman. This was the optimum situation within that period. ${ }^{17}$ The religious courts outside the capital Jakarta always housed fewer judges, with very few in certain periods. This disproportion in the number of judges outside Jakarta was because fewer cases had to be examined

${ }^{14}$ Nurlaelawati and Rahim enumerate the qualifications in "The Training, Appointment and Supervision of Islamic Judges in Indonesia," p. 49. The letter specifies a minimum age of twenty-five for judges and a mandatory retirement age of sixty. Candidates for the bench must provide medical proof that they are drug-free. The Supreme Court has also established height requirements for judges. To be appointed as a judge, men must be at least $160 \mathrm{~cm}$ ( 5 feet 3 inches) tall and women must be at least $152 \mathrm{~cm}$ (5 feet) tall.

${ }^{15}$ The first session consists of two examinations, one testing "basic competency" (Tes Bakat Skolastik/TBS), which includes cognition, psychosomatics and mathematics, with a second one on "general competency," which covers civic knowledge, languages, history, and government administration. The examination administered in the second session tests both specific knowledge (Tes Pengetahuan Khusus/TPK) and specialized or substantive knowledge (Tes Kemampuan Bidang/TKB). This encompasses Islamic law, the procedural and substantive law of the Islamic courts, and Islamic astronomy (bisab rukyat).

${ }^{16}$ Euis Nurlaelawati and Adurrahman Rahim, "The Training, Appointment," p. 57.

${ }^{17}$ Euis Nurlaelawati, Modernization, Tradition, and Identity: The Kompilasi Hukum Islam and Legal Practices of the Indonesian Religious Courts (Amsterdam: Amsterdam University Press, 2010). 
outside the capital. ${ }^{18}$

Promotion and demotion of judges from one region to another has been a factor that explains why one court office might have more or fewer judiciary personnel than the other. Nurlaelawati recounted that in 2005, for example, the religious court of Cianjur employed nine judges; the religious court of Rangkasbitung had nine; the religious court of South Jakarta had ten, as did the court of East Jakarta. One year later, the number of judges in both courts located in the capital Jakarta remained constant, while fewer judges were employed in the Cianjur and Rangkasbitung religious courts. The number of judges in the court of Rangkasbitung fell from nine to six. In the Cianjur religious court, the number of judges fell to seven after two were posted to other districts. Apparently, no new judges were sent to replace those judges who were promoted or demoted to other posts. ${ }^{19}$ Nevertheless, the number of judges in these two religious courts has changed recently. According to the data issued in 2012, the religious courts of both Cianjur and Rangkasbitung now have eleven judges. ${ }^{20}$

\section{Women in the Islamic Judiciary in Indonesia}

Women engagement in the public professions or holding down jobs in the labour market has been a long-standing cultural phenomenon in Indonesia. Thanks to the local tradition of economic partnership between husband and wife, women or wives in Indonesia have for many centuries not been prevented from actively supporting their spouses working in the fields, cultivating lands and harvesting rice, or selling food or garments in the market. Although it is not acceptable according to Shafi i Islamic jurisprudence, to which the majority of Indonesian Muslims subscribe, this economic partnership helps explain why the local practices of many Muslim ethnic groups in Indonesia recognize and accommodate the concept of joint marital property between husbands and wives. ${ }^{21}$ As

${ }^{18}$ Ibid., p. 34.

${ }^{19}$ Ibid.

${ }^{20}$ See Profile of religious court (PA) of Cianjur, at http://pa-cianjur.go.id. See also Profile of religious court (PA) of Rangkasbitung, at www.pa-rangkasbitung.go.id.

${ }^{21}$ Mark E. Cammack and R. Michael Feener, "Joint Marital Property in Indonesian Customary, Islamic, and National Law" in Peri Bearman, Wolfhart Heinrichs, Bernard G. Weiss (eds.), The Law Applied: Contextualizing the Islamic Shari"a, a Volume in 
women in Indonesia have had rights and access to property for a very long time, their engagement in paid jobs in both government public positions and private professional sectors is mostly welcomed. A recent study has confirmed that a majority of the Indonesian population support women who work or even hold top positions in offices, and consider women's engagement in the public sector as important as in the domestic cultural sphere. ${ }^{22}$

Over the course of time there has been a general increase in the number of female employees in Indonesia's judicial structure. It is worth mentioning that 28 females have now been appointed to serve as judges in the Supreme Court, the highest court in Indonesia's legal structure. Initially, in the late 1950s, five female legal scholars were appointed as the first women judges to serve in the lower civil courts in different cities. In 1968, the first female judge appointed to the Supreme Court was Sri Widoyati Wiratmo Soekito. Since then, more women have been recruited to become Supreme Court's judges. Almost fifteen years later, in 1983, nine female judges were sitting on the Supreme Court bench, falling to eight in $1992 .{ }^{23}$

This example of female judges in the Supreme Court clearly illustrates how women, even if only a small number of them, can hold professional positions in Indonesia's judiciary institutions. The positions were not limited to the civil courts but were also available in the Islamic courts, as shown above. Indonesia's experience of recruiting female judges to Islamic courts would not have been possible in Malaysia, its neighbouring Muslim country, decades ago. In fact, although Malaysia has a long history of appointing Muslim women to the general judicature, it was only in 2010 that the Malaysian Sharia Court appointed a woman, when two female judges, Rafidah Abdul Razak and Suraya Ramli, started working in a Sharia Court. Their appointment was considered a step toward women's equality despite the fact that the governing council for the Sharia Court system initially announced that severe limits would be

\footnotetext{
Honor of Frank E. Vogel (London: Tauris, 2008), pp. 92-115.

${ }^{22}$ Christina Fattore, Thomas J. Scotto, and Arnita Sitasari,"Support for Women Officeholders in a Non-Arab Islamic Democracy: The Case of Indonesia," Australian Journal of Political Science, vol. 45, no. 2, June 2010, pp. 261-275.

${ }^{23}$ Sebastian Pompe, The Indonesian Supreme Court: a Study of Institutional Collapse (Cornel: Cornel University, 2005).
} 
placed upon women's duties, such as adjudicating criminal and divorce cases. However, there was a reaction and a debate about this limitation, which finally led the council to announce that female judges would be instated with full powers. The critical response was able to turn what could have been a setback for women's rights into a full-fledged victory. ${ }^{24}$

In the first two decades after Indonesia's independence (1945), the recruitment of female judges to serve in the Islamic court attracted protest from some conservative Muslim groups. Despite the fact that the general court had appointed female judges in late 1950s, they considered the women sitting on the bench of the Islamic courts was a violation of Islamic legal tradition, especially the Shafi i juristic doctrine. It was stated that the reason for denying women the right to be a judge in Muslim contexts was based on the hadith "people who appointed a woman over them will never succeed". Although the context of this hadith was the fact that the daughter of the Persian king had been appointed as a new ruler after her father's death, some Muslim jurists, including the Shafi $i$ legal scholars, placed a restriction on women from occupying any public position.

In response to this criticism, the Directorate of Religious Justice of the Ministry of Religious Affairs issued a clarification, assuring that the appointment of women judges to Islamic courts has a strong basis in Islamic legal theory. ${ }^{25}$ The Directorate justified the recruitment of women to serve as judges in Islamic courts by referring to a notion of necessity or legal emergency (darüra). The appointment of women judges was considered d̦arura because Indonesia lacked qualified Islamic judges and even many male judges who were at that time employed in the Islamic courts did not meet the full requirements, such as standard knowledge of Arabic and familiarity with classical Islamic legal references. In addition,

${ }^{24}$ Pamela K. Taylor, "Malaysia appoints first female Sharia judges," http://www. faithstreet.com/onfaith/2010/08/07/malaysia-appoints-first-female-sharia-judges/290, August 7, 2010, and Ajeng Rizki Pitakasari, "Malaysia Tugaskan Hakim Wanita Pertama di Pengadilan Agama," at http://www.republika.co.id/berita/dunia-islam/ islam-mancanegara/10/07/10/123981-malaysia-tugaskan-hakim-wanita-pertama-dipengadilan-syariah, July 9, 2010, accessed in June 25, 2013. See also Djazimah Muqaddas, Kontroversi Hakim Perempuan pada Peradilan Islam di Negara-negara Muslim (Yogyakarta: LKiS, 2011).

${ }^{25}$ Hermansyah, "Hakim Perempuan di Peradilan Agama. 
as Lev noted, the appointment of women judges did not constitute "an overwhelming threat to any essential interest". ${ }^{26}$ Apparently, what had been conceived as a crucial threat to the Islamic courts at that time was the stronger jurisdiction of other tribunals, the civil courts (Pengadilan Negeri) in particular. As Islamic courts were subordinated to general courts, especially in relation to the issue of 'fiat of execution' (executoire verklaring), many Muslim leaders were extremely unhappy that the civil courts had full control over Islamic courts' jurisdiction on Muslim family law, and hence criticised this biased legal structure. ${ }^{27}$

\section{Initiative Recruitment of Female Judges}

The recruitment of women to act as judges in an Islamic court was a gradual process of legal modernization in the first decades after Indonesia's independence. It started at a local level with a small number. Once it began and spread out to other regions, however, it became unstoppable and turned out to be an acceptable change, even to those who had initially opposed it in Islamic circles. In an interview with the Directorate of Religious Justice, Lev discovered that the top official in this institution, Zabidi, was the person in charge who strongly supported the appointment of women judges. He commenced this plan in the small district of Tegal in Central Java province. Zabidi himself was from this district and therefore he felt confident he could deal with any resistance to his program from Islamic circles should it occur. ${ }^{28}$

By late 1964 there were 15 female part-time judges and one full-time judge serving the district religious court of Tegal. At about the same time, Zabidi stated that there was one woman of high social rank from Pekalongan (also a district in Central Java) who applied for an appointment as a judge in the Pekalongan district religious court, a request which Zabidi certainly approved. Female judges serving in Islamic courts in this period were only a rare local phenomenon. A male judge from Padang, West Sumatra, who was present when Lev was interviewing Zabidi, confirmed that female judges serving Islamic courts would be

${ }^{26}$ Daniel S. Lev, Islamic Court, p. 110.

${ }^{27}$ See Ratno Lukito, "Law and Politics in Post-Independence Indonesia: a Case Study of Religious and Adat Courts," in Arskal Salim and Azyumardi Azra (eds.), Sharia and Politics in Modern Indonesia (Singapore: ISEAS, 2003), pp. 26-27.

${ }^{28}$ Daniel S. Lev, Islamic Court, p. 110. 
unimaginable and unacceptable to people in his hometown, despite the fact that Muslims who live in this province live in a strongly matriarchal society. In response, Zabidi strategically emphasized that the Directorate of Religious Justice's program to appoint female judges to Islamic courts would be moving slowly and would be limited to Java. ${ }^{29}$ Ten years later, this program became popular and some regions outside Java began to participate.

Jumping now three or four decades later, Zabidi's initiative had become a major trend and from the mid-1990s onwards, almost each district religious court office has employed female judges. Although the majority of the judges in district religious courts are male (reaching up to $80 \%$ in some cases), female judges can still be found sitting on the bench in religious courtrooms. Indonesia was thus one of very few Muslim countries to initiate the engagement of women in the legal profession and judicial system.

\section{Educational Backgrounds of Female Judges}

The 1989 Religious Judicature Act stated that, as noted above, prospective judges have to meet a number of requirements to become judges in both the Islamic and the civil courts. In terms of education, they must have at least a bachelor's degree in sharia law and law. While the Islamic law graduates could not become judges in the civil courts, those from the law faculty were able to work as judges in Islamic courts, with the requirement that they must have a good understanding of Islamic law. However, although the minimum educational requirement is only a bachelor degree, a growing number of religious judges have obtained master and doctoral degrees. In 2009, there were 842 first-instance judges with higher degrees. As of 2009, there were more judges with postgraduate degrees in the appellate courts than judges with equivalent degrees in the first-instance courts. In fact, more than half of all judges in the appellate court had obtained masters or doctoral degrees. ${ }^{30}$

If one classifies the number of judges with advanced degrees by gender in the first-instance courts, the number of male judges with advanced degrees is proportionally higher than that of female judges

\footnotetext{
${ }^{29} \mathrm{Ibid}$.

${ }^{30}$ Euis Nurlaelawati and Abdurrahman Rahim, “The Training," p. 50.
} 
with advanced degrees. Thirty per cent of male first-instance judges had advanced degrees in 2009 compared to 21 per cent of female judges. However, this is not the case in the appellate courts, as the proportion of advanced degree holders is essentially the same for male and female judges; just over $50 \%$ of the judges in both gender groups have advanced degrees. ${ }^{31}$

Few female judges have earned doctoral degrees. In 2010, one female judge, Djazimah Muqaddas, promoted her doctoral thesis in the State Islamic University of Sunan Gunung Djati, Bandung. ${ }^{32}$ As of 2012, 389 judges have doctoral degrees and of these, three are females. ${ }^{33}$ The number will increase in about four years as two female judges, viz., Dra. Burnalis, M.A., a vice director of PA Bengkalis and Dra. Hj. Nursyamsiah, MH, a senior judge, have been reported as having enrolled in a doctoral programme in 2013. Their enrolment in the doctoral program was facilitated by joint work by the Appellate Islamic Court of Pekanbaru and the State Islamic University of Syarif Qasim in Riau. Together with their 17 male counterparts, these two female judges registered to take the challenge of higher education. ${ }^{34}$

\section{Number and Positions of Female Judges in Islamic Courts}

The presence of female judges on judicial boards is often associated with the resolution of gender inequality in the legal practice of the Muslim world, including in Indonesia. The persistence of gender inequality has led to the thought among persons concerned with gender issues, that women should be involved on judicial boards. Such people, including activists for the rights of women, hope that the inclusion of women on

${ }^{31}$ Ibid.

32 "Muqoddas: Doktor Wanita Pertama Bidang Hukum Islam di UIN Sunan Gunung Djati Bandung," http://www.badilag.net/index.php/pengaduan/315-beritakegiatan/6107-sidang-terbuka-promosi-doktor-atas-promovendus-hj-djazimahmuqoddas-219, accessed on 18 September 2010.

${ }^{33}$ Hermansyah, "Profesor dan Doktor: Tujuh Hakim Lakukan Pembaharuan Hukum Islam,” http://www.badilag.net/component/content/article/315-beritakegiatan/14983-professor-dan-doktor-tujuh-hakim-agung-lakukan-pembaruan-hukumislam-283.html, accessed on 28 March 2013.

34 “"Dua Srikandi PA Bengkalis Melanjutkan S-3," http:/ / www.badilag.net/beritaseputar-peradilan-agama/15231-dua-srikandi-pa-bengkalis-melanjutkan-s-3--104.html, accessed on 10 April 2013. 
judicial boards will/can minimize, if not eliminate, the problem of gender inequality. The idea that women's engagement is crucial in the public sector has led the government to pursue a policy that women should fill $30 \%$ of vacancies in several sectors, including politics and the judiciary.

Although the appointment of female judges to Indonesian Islamic courts began in the 1960s, as mentioned above, and has run formally since 1989, there are still fewer female judges than male ones. Referring to a report issued in 2011, which is available on the website of the Directorate of Religious Court (www.badilag.net), the percentage of female judges is around $15 \%$ or more of the total. While the total number of judges in the first-instance and appellate courts throughout Indonesia is 3,687, only 507 were female (471 in the first-instance and 36 in the appellate court). The gender composition of roughly between $80 \%$ male and $20 \%$ female also holds for almost every district religious court, where two or three out of 10 to 11 judges are female. ${ }^{35}$

There are three principal factors that explain the relatively small number of female judges in the Islamic courts. The first is the widespread, incorrect notion among some Muslim circles that women are sensitive, emotional and irrational. This still influences some Muslim women and prevents them from holding crucial decision-making positions in both Islamic and civil courts. ${ }^{36}$ The second is the kind natural tasks undertaken by judges, which are thought to be hard and difficult for women to carry out. In interviews with six female graduates of the faculty of sharia, it was discovered that that the majority of women are reluctant to apply for the position of judges because they see judges as having to perform a hard task. ${ }^{37}$ Judges have an obligation to resolve cases brought before them and to examine them carefully and fairly. Where the task cannot be entirely finalized in the courtroom, the judges should take the case home (at least in their thoughts). Since most lawsuits cannot be settled immediately or within only a single hearing, judges therefore cannot free themselves, even though they are at home. In the current situation, many

\footnotetext{
${ }^{35}$ Euis Nurlaelawati, Modernization, Tradition, and Identity, p. 34.

${ }^{36}$ See Any Widyani Soetjipto, "Big Party Politics: Still A Man's World?," A Report on Indonesia, at http:/ / library.fes.de/pdf-files/bueros/philippinen/04527/08-indonesia. pdf, p. 56.

${ }^{37}$ Interviews with three respondents, HY and NF, July 2010, Jakarta, and AM, November, 2013, Yogyakarta.
} 
female law graduates consider a non-physical burden to be inappropriate to the condition of women. They tend to avoid the dual burden of work both at home and in the office. Working as a part-time judge, as in the 1960s, could possibly be a solution to this problem. Female judges who work part time may flexibly allocate their time between office and home. However, part-time positions have no longer been available since the early 1990 s.

The third issue is system whereby newly appointed judges are placed with a district, which may not be their own preference. Newly appointed judges are more likely not to be sent to favourite areas. Although this placement system applies to all newly appointed civil servants in all state institutions, the system applied in the judiciary (in terms of placement in remote areas) is more apparent than in other state agencies. Prior to taking up or commencing their job, judges have to agree and be prepared to relocate elsewhere, even to the remote areas of Indonesia, on the instruction of the Supreme Court. Matters are quite different for newly appointed civil servants in fields other than the judiciary. Although they also have to sign a letter stating their willingness to relocate at anytime, anywhere in Indonesia, these government employees are more fortunate in that they are mostly assigned to locations where they applied for the positions of civil servants. Newly appointed judges, however, have no option and are mostly sent off to remote areas. ${ }^{38}$

Coupled with the heavy burden they would have to carry, female law graduates have to think over and carefully take everything into account before applying for a position as judge, because the assignment should commence as soon as the decision about the appointment of judges in a district court has been taken. ${ }^{39}$ For this reason, a job as a judge is not one of the favourite public professions for women in Indonesia. In the view of these women who prioritize their responsibility as both wife and mother, judicial positions are not especially attractive jobs. It is no wonder, then, that the number of female graduates who apply for positions as judges in both the Islamic and the civil courts has never been similar to the male applicants. In the 2009 recruitment, for an example, July 2013.

${ }^{38}$ Interview with one of the female judges in the Islamic court of Yogyakarta,

${ }^{39}$ See Euis Nurlaelawati, Modernization, Tradition, and Identity, p. 34. 
applications for judicial positions decreased significantly compared to the number of applicants prior to 2009. While the Supreme Court received 100 applications in $2008,{ }^{40}$ only 75 applications were submitted in $2009 .{ }^{41}$ Of these, only 19 were from women.

The Head of the Supreme Court Department of Youth Development, as quoted by Alia Hasna Ruslan, a senior judge in the Islamic court of Karawang and a former vice chairman of the Islamic court of Cilegon in her paper presented to a workshop on improving the quality of the resources in the Islamic courts, acknowledged that the number of female judges in religious courts is still limited, because unlike men, women are less interested in being judges. According to this official, this situation explains why the required $30 \%$ of women involved in decision-making processes has not yet been achieved. She quickly added that all this has nothing to do with structural barriers. Rather, it was all internally driven by factors specific to women themselves, namely women's inability and their lack of interest. ${ }^{42}$

The above factors are reinforced by the fact that more women in the religious court offices are working in administrative units. Most of these positions are not necessarily rotated and relocated to other places. As of 2011 it is recorded that of 3,247 clerks, 1,183 or about $35 \%$ are women. This means that women actually do not avoid employment by the court; they simply do not prefer to serve as judges. The nature and burdens of the judge's work have discouraged a lot of women from applying for a judge's position in the Islamic court. Employment as bailiff has been the goal and interest of many women. According to the 2011 statistical data, there were 1,167 bailiffs working in the religious courts throughout Indonesia. Twenty per cent of this number, or 297, are female bailiffs.

Regardless of the smaller number of female judges, clerks and

${ }^{40}$ This was the number that was decided by the Ministry of Pendayagunaan Aparatur Negara in the letter identified as No. B/28.F/M.PAN/8/2008, dated 04 August 2008.

41 "Calon Hakim PA Harus Lebih Kuasai Hukum Acara Jakarta," http://www. pa-pandeglang.go.id/index.php/info-perkara/16-berita/info/50-calon-hakim-pa-haruslebih-kuasai-hukum-acara, accessed on Friday, 18 January $2013 .$.

${ }^{42}$ Alia Hasna Ruslan, "Peradilan Agama, Hakim Perempuan dan Penegakan Hukum Berkeadilan Gender," http://www.badilag.net/index.php?option=com_cont ent\&task $=$ view\&id $=895 \&$ Itemid $=54$, accessed on 28 December 2007 . 
bailiffs (if compared to the number of men), one can say that the presence of women personnel, in both technical and non-technical positions, in the Islamic judiciary system of Indonesia is genuinely tangible. In total, women contribute to about one-third of the personnel in the Islamic judiciary. Of 11,743 technical and non-technical employees, 3,944 are female. ${ }^{43}$ This is certainly a significant development, especially when compared to other Muslim majority countries.

In any case, optimism about the increase of women's participation in the judicial Islamic institutions of Indonesia remains high. For one thing, the concept of ulama, which is usually identified with men, has been criticized and challenged by a number of prominent ulama.${ }^{44}$ For another, current state policy encourages women to occupy more spaces in public engagement, including work in judicial institutions. The gender policy that requires a minimum ratio of $30 \%$ of women in decision-making positions is the source of this optimism. Many female judges have now occupied a position as chairperson in religious court offices. While no single chair of a religious court office was held by a woman before 2000 , currently some women have assumed a position as the head of an Islamic court. As of 2009, twenty female judges had been appointed to chair the first-instance Islamic courts. According to statistical data available on the Badilag's website issued in 2007, the Indonesian Islamic Courts still required more personnel to serve as judges at the first-instance religious courts. The total need was for about 5,229 judges. While in that year there were 2,913 judges, about 2,316 or $45.30 \%$ positions were available. This means that more vacancies and opportunities were open to women to serve as judge in the Islamic courts in 2007 , which had not been fulfilled until 2013.

Above all, the discussion of women participating in judicial boards including the Islamic judiciary has attracted wide public attention. The main issue has been the problem of the shortage of judges and the significant difference in number between male and female judges. In her paper as noted above, Dra. Alia Hasna Ruslan posed question as to whether the problem is due to the poor quality of women themselves

\footnotetext{
${ }^{43}$ Hermansyah, "Hakim Perempuan di Peradilan Agama.

${ }^{44}$ Asrori S. Karni, "Prof. Ibrahim Hosen: Mujtahid Fatwa Bergelimang Pro dan Kontra," Gatra, 6 May 2009.
} 
or to a policy that sets a limitation. In response, she offered a number of relevant people's views related to the issue. ${ }^{45}$ It was pointed out that the poor engagement of women in judicial positions had several causes and therefore some programmes or changes were required to attract women to the judicial boards. The first is coaching in personnel administration and a management system for workplace transfer. The second is increased objectivity, transparency and fairness in the implementation of the workplace transfer with respect to the promotion of gender awareness. The third is an attempt to increase professionalism, development and rationalization of the judicial personnel, which may also reach a solution about women being transferred to remote areas. To reinforce her argument, Hasna referred to the Indonesian justice system, stating that there is no gender bias in the recruitment of judges. As far as the ratio of $30 \%$ of female involvement in decision-making is concerned, Hasna contended that this gender policy implies that women's engagement can be more or less than $30 \%$. So, in Hasna's view, it is not a restriction for women to develop their judicial career, and female judges have the same opportunity as their male counterparts. Furthermore, every judge, regardless of gender, could improve his/her career and it is not their gender, but their ability and professionalism that would define their career progress. In regard to recruitment, to employ more women in Religious Court, a female judge might be prioritized under certain conditions. An example given was that if there is only one male judge and one other female judge with the same qualifications to be appointed to a post as head of Islamic court, the female judge would be preferred.

\section{Legal Notions of Female Judges on Gender Issues}

Since their establishment, the Islamic courts have had jurisdiction mainly on familial issues, which has widened since 2006 to Islamic economic issues. Familial cases that reach the Islamic court are mostly divorce, with petitioners mostly women or wives. According to some studies, more women attend court and petition for divorce than men. ${ }^{46}$

${ }^{45}$ Alia Hasna Ruslan, "Peradilan Agama, Hakim Perempuan."

${ }^{46}$ Sumner and Lindsey, Courting Reform: Indonesia"s Islamic Courts and Justice for the Poor (New South Wales: Lowy Institute, 2010), pp. 32-33. See also Mark. E. Cammack, et.al, "Islamic Divorce Law and Practice in Indonesia," in R. Michael Feener and Mark E. Cammack (eds.), Islamic Law in Contemporary Indonesia (Cambridge: Harvard University 
This has led to the idea that female judges are necessary as they are deemed to have the same feeling and are more able to better understand the problems experienced by women, including their diverse social status and ethnic-group backgrounds. Despite the small number of female judges in Indonesia's Islamic courts, the emerging question concerns the extent to which female judges have contributed to solve problems of gender inequity in legal transactions.

Many studies have been done on the way the judges of the Islamic courts make their decisions. Some investigators particularly paid attention to gender equality in the courtrooms, while others focused on contending argumentations between different norms, including gender equality, within the disputes examined in the religious courts. ${ }^{47}$ Hirsch's study in Kenya, for an example, revealed that the majority of marital conflicts handled by the local Islamic courts are initiated by women and ended in their victory. According to Hirsch, this success lay in the female litigants' strategy to transform the perception of womanhood to their advantage in their disputes with their husbands. Instead of accusing their husbands shamefully, they made a claim against their husbands indirectly. Additionally, Hirsch pointed out that the success of female litigants was also due to the fact that the Islamic judges sided with these women in order to look for ways to reinforce their authority with the public, especially against the pressure of local elders or other Muslim men. ${ }^{48}$ Hirsch's study demonstrated how gender notions in Kenyan Islamic courts reflected the way women litigants were active agencies, negotiating

Press, 2007), and Euis Nurlaelawati, "Indonesian Muslim Women at Court: Reform, Strategies and Pronouncement of Divorce," Journal of Islamic Law and Society, Leiden: Brill, 20: 3, 2013.

${ }^{47}$ See works by June Starr, Law as Metaphor: from Islamic Courts to the Palace of Justice (New York: SUNY Press, 1992); Annelies Moors, Women and Property in Islam: Palestinian Experiences 1920-1990 (Cambridge: Cambridge University Press, 1995); Judith Tucker, In the House of the Law: Gender and Islamic Law in Syria and Palestine, 17th-18th Centuries (Berkeley: California University Press, 1998); Susan F. Hirsch, Pronouncing and Persevering: Gender and the Discourses of Disputing in an African Islamic Court (Chicago: University of Chicago Press, 1998); Michael G. Peletz, Islamic Modern: Religious Courts and Cultural Politics in Malaysia (Princeton: Princeton University Press, 2002), and John Richard Bowen, Islam, Law, and Equality in Indonesia: An Anthropology of Public Reasoning (Cambridge: Cambridge University Press, 2003).

${ }^{48}$ Susan F. Hirsch, Pronouncing and Persevering, p. 129. 
their rights and claims. However, the way female judges examine and approach a case when women are the complainants was not touched on in Hirsch's study, mostly because female judges did not exist when Hirsch undertook her fieldwork in the 1990s; in fact, the introduction of female judges into the Islamic court of Kenya in 2011 was opposed in Islamic circles. ${ }^{49}$ In general, the topic of female judges who employ gender approaches is understudied, as many works on Islamic courts were silent on this particular issue.

In Indonesia, female litigants also deployed strategies to convince judges that their petitions for divorce are based on valid grounds. Before 1974 divorce was more difficult for women to initiate because they had to petition the court. By contrast, when men sought a divorce, they only need to see registrars at the sub-district office of religious affairs. Since 1974, however, both women and men have been required to go to court and present one or more valid grounds, as specified in the Law of Marriage and the Kompilasi Hukum Islam/KHI, to be granted a divorce. ${ }^{50}$ Although legitimate grounds for divorce are the same for men and women, there is marginally different procedure that applies to women, to their (dis)advantage. By exploring a number of reasons noted in court, Nurlaelawati's study discovered that to win their cases, women not only presented grounds for divorce and asserted their conviction before the judges, but also made significant statements about their marital conditions. She gave examples where wives who mostly petitioned for divorce on grounds of economic problems have no fear of bearing the financial burden after divorce, because they were already bearing it, or their extended family would bear it and would be willing to bear any stigma they might receive after a divorce. ${ }^{51}$ Nevertheless, in common with the other works mentioned earlier, her study did not pay special attention to the attitude of female judges.

\footnotetext{
${ }^{49} \mathrm{http}$ // /www.onislam.net/english/news/africa/452685-kenya-muslims-splitover-female-judges.html

${ }^{50}$ See article $116 \mathrm{KHI}$ and the Elucidation of the Law of Marriage. For good discussion on the proceeding of divorce, see Hisako Nakamura, Divorce in Java (Yogyakarta: Gadjah Mada University Press, 1983). See also John Bowen, "Shari"a, State and Social Norms in France and Indonesia," Institute for the Study of Islam in the Muslim World (ISIM) Lectures (Leiden: ISIM, 2001).

${ }^{51}$ Euis Nurlaelawati, "Muslim Women in Indonesian Religious Court."
} 
It is often thought that due to their emotional nature, female judges would serve the interests of women claimants better than male judges, and female judges are thus more lenient in promoting gender equity in their legal decision making, more so than male judges. Based on a number of case studies of female judges serving in Indonesia's religious courts and the numerous family disputes they have examined, it was found that, besides their natural sensitivity as women the key reason why women judges feel more inclined to defend the interests of female litigants has also to do with their attendance and active involvement in particular training sessions of women's empowerment programs. These training courses enhanced their gender sensitivity by multiple teaching methods and interactive discussions with authoritative sources. ${ }^{52}$

From 2006 to 2009, two women's organizations (the Center of Women Studies of Sunan Kalijaga State Islamic University and Putroe Kandee Foundation of Aceh) had worked separately to enhance the gender sensitivity of religious court judges and Islamic registrar officers in various parts of Indonesia in the area of family law. With support from the Asia Foundation, the gender sensitivity training organized by these two organizations sought to foster a gender equity approach among religious officials who deal with legal and gender relations between men and women in family life. The training was to open up new perspectives for judges in order to allow them to improve their sensitivity in exploring the inequities in husbands' and wives' access to and control of resources. This kind of inequity may take the form of unfair verdicts on joint property and custody cases, which are often produced by gender-biased decision-making methods, where judges strictly refer to the Quranic verses or classical legal doctrine of one school of Islamic law. Some judges, for example, often dismissed women's right to custody of their under-aged children, below 12 years old, on the ground of the mother's apostasy. ${ }^{53}$ Through these training sessions, judges in religious courts were able to gain a broader and fairer perspective, which they can apply when dealing with gender injustice in nearly all family disputes. With this

${ }^{52}$ Arskal Salim et.al., Demi Keadilan dan Kesetaraan. pp. 26-50.

${ }^{53}$ See Euis Nurlaelawati, Modernization, Tradition and Identity, p. 144. See also her recent report research, "Shari" a-based Laws: The Legal Position of Women and Children in Indonesia," in Regime Change, Democracy, and Islam: The Case of Indonesia (A Final Report Islam Research Program), 2013, 38-39, www.hum.leiden.edu., accessed on 3 March, 2013. 
gender notion in mind, the judges of different Islamic courts became motivated and felt themselves legitimated to reinterpret the texts of laws and regulations that contain injustice and gender bias, such as those on polygamy and custody, or to go even further, beyond the legal texts, to uphold the essence of justice. ${ }^{54}$

Participants in the gender sensitivity training programs included male and female judges. In almost every training program conducted in different times and places in three provinces of Indonesia, male judges outnumbered the female judges in attendance. Despite this, female judges made non-gender-biased decisions that were as good as male judges in some cases, such as joint property and divorce cases. Even, in certain situations, female judges demonstrated greater gender sensitivity than their male colleagues. In the case of eligibility to be a legal guardian of orphaned children in Aceh, following the post-tsunami recovery process, many Islamic jurists and traditional religious teachers considered that the rule of guardianship for those orphaned children, including the management of the estate that the children inherited from their deceased parents, is similar to marriage guardianship. This meant that should parents and other immediate male family members have died or gone missing in the tsunami disaster, the responsibility of guardianship should go to the male relatives of the children, even if they are distant kin or live far away from the children. ${ }^{55}$

Female judges in Aceh's religious courts, however, were prone to appoint female relatives or family members of the children's mother to take over this responsibility. In the view of these women judges, as far as the cultural context of Aceh is concerned, children usually feel more comfortable living with their female relatives or their mother's relatives. ${ }^{56}$ Unlike Minangkabau people who live in the other province of the same island and embrace a matriarchal family system, Aceh in principle is a patriarchal community. However, Aceh has a system of matri-local residence, where newly married couples would be likely to stay at the bride's parent home or in a house granted to the bride by

${ }^{54}$ Arskal Salim et.al., Demi Keadilan dan Kesetaraan, pp. 52-86.

55 Arskal Salim, Praktek Penyelesaian Formal dan Informal Masalah Pertanahan, Kewarisan dan Perwalian Pasca Tsunami di Banda Aceb dan Aceh Besar (Banda Aceh: IDLO, 2006).

${ }^{56}$ Arskal Salim, et.al. Demi Keadilan dan Kesetaraan, p. 54. 
her parent. This in turn leads children to attach more closely to their mother's family. As of March 2006, less than two years after the tsunami, both Sharia Courts in Banda Aceh and Jantho had appointed 100 female relatives (of 243 all appointed guardians), to act as legal guardians for the orphaned children. These female guardians included elder sisters, aunts or grandmothers from the children's mother's side. ${ }^{57}$ It may be considered that this case is about sensitivity to cultural norms rather than gender sensitivity. Although there may be some truth to this statement, it should be understood that what the (female) judges in Aceh were trying to do was deploy their sensitivity to cultural norms as a means to justify the application of gender sensitivity for this case. In so doing, they would be able to avoid unnecessary resistance from within the community should they base their decision exclusively on gender notion.

Apart from the issue of female guardianship, female judges expressed concern and gender sensitivity more than their male counterparts, something which is also observable in the case of divorce. In this case, it is worth describing an experience of a female judge from Aceh, Rosmawardani, who was actively involved in the gender sensitivity training described above. Serving as vice chairman of the district Shari'a Court in Jantho, she was once confronted with a case where a wife had petitioned the court for a divorce. The wife considered her husband to be an irresponsible person since he failed to fulfil his marital obligations, such as offering her regular financial support and providing her with sexual access. Despite this, the wife actually had no lawful ground that would strongly support her petition. This was because one of the grounds that permit divorce is the husband's lack of maintenance for more than three months. Although the husband rarely returned home every day or week to undertake his duties, he remained faithful to his wife, neither having a second wife nor doing violence to her. More importantly, he accidentally came home within the three-month time frame, gave a little money to his wife, and stayed for a couple of weeks before making the next trip. One thing that motivated the wife to seek a divorce from her husband was because she was no longer happy with her marriage. Judging from the applicable textual laws, there was no explicit excuse that would allow judges to dissolve this couple's marriage.

\footnotetext{
${ }^{57}$ Arskal Salim, Praktek Penyelesaian, p. 47.
} 
Considering the wife's distressful situation and her unhappiness, Judge Rosmawardani nevertheless went beyond the text and gave her view that the couple's marital relationship could be ended by reinterpreting divorce stipulations specified in both the 1974 Marriage Law and the Kompilasi Hukum Islam/KHI. Judge Rosmawardani made a new interpretation of penganiayaan berat (severe ill-treatment) -one of the reasons that may lead to divorce- in that it should be understood more in its emotional and mental implications, and not necessarily be proven by physical injuries only. Before the court made a final decision on this case, two of Rosmawardani's male colleagues, who were in the same judiciary panel, challenged the way she had reinterpreted the legal text. They both refused such legal reinterpretation because it went beyond the text and was not a proper application of Islamic law. To this internal criticism, Judge Rosmawardani explained the gender concept of nonphysical violence in the family and assured her two colleagues that what they were going to decide was not incorrect. Finally, all panel judiciary members agreed and issued a joint court decision. ${ }^{58}$

As far as the issue of polygamy is concerned, Acehnese female judges stressed that polygamy is permitted, but its application is strictly limited. They often warned their male counterparts to be suspicious and careful of any husband's polygamy proposals. A male judge who happened to hear a case for a polygamy permit application was very aware that polygamy would distress wives, and he finally was able to convince a husband to withdraw his proposal. ${ }^{59}$

However, what happened in Aceh's Islamic court was not necessarily shown in other district Islamic courts, such as in Tangerang. Despite the fact that a number of female judges of religious courts in Tangerang admitted to having received training on gender sensitivity (and many did acknowledge they were receptive to gender issues), in practice they appear not to have demonstrated such receptivity properly. Taking an example of their judgements on polygamy cases, no significant difference, in term of substance, was found between those decisions issued by a panel in which a female judge was involved and the ones decided by a panel with no female judge. As an illustration, judgment

\footnotetext{
${ }^{58}$ Arskal Salim, et.al., Demi Keadilan dan Kesetaraan, p. 63.

${ }^{59}$ Ibid., p. 77.
} 
no. 280/001/Tgr/2009 was decided by a panel where a female judge was involved. In this case, the proposal of polygamy by a husband was approved, even though the reason he presented was not lawful, i.e., the husband had been so close to his prospective that he was afraid that he felt into sin from committing zina or extra-marital intercourse. A decree that goes along the same line is revealed in judgement No. 322/ 003/ $\mathrm{pdt} / \mathrm{Tgr} / 2009$, where the husband wished to have more children while his existing wife who had given birth to two children could no longer be pregnant. Two earlier judgements, identified as No. 211/ 003/Pdt/Tgr/ 2008 and No. 164 002/Pdt/Tgr/2008, were issued by a panel involving another female judge in the same court and demonstrated that female judges have not been more responsive than their male counterparts in gender issues.

All these decisions by the Tangerang religious court can probably be interpreted in two ways. The first is that, compared to male judges, female judges were not responsive or sensitive to gender issues, at least in case of polygamy. It might also be suspected that female judges in this court did not have good understanding of gender equity. The second is that female judges have some levels of gender awareness, but the panel system that applies in Indonesian judiciary ${ }^{60}$ might have prevented female judges from expressing their gender sensitivity much more clearly, so as to argue against their male counterparts.

Given the fact that Acehnese female judges have often succeeded in ensuring their male counterparts support their legal interpretation, it can probably be assumed that the first interpretation above is much more accurate than the other. In fact, all the judgements issued by panels involving female judges mentioned above went along the same line, demonstrating that none of those female judges in the Tangerang religious court made any strong endeavour, unlike their female counterparts in Aceh religious courts who contended against the voice of their male colleagues. This interpretation was confirmed by conversations and debates in an academic forum attended by a number of the Islamic court judges, including female judges from Tangerang religious court.

${ }^{60}$ For the rule on this system, see Religious Judicature Act, Act No. 7 of 1989 , arts. 9-10, and Basic Act on Judicial Power, Act No. 4 of 2004, art. 17(1). For the discussion on the panel system in Islamic judiciary in Indonesia, see Mark. E. Cammack and Michael Feener, "The Islamic Legal System in Indonesia." 
The forum addressed the issue of access to Islamic justice and was divided into several sessions, one of which was devoted to legal issues concerning women. When the issue of polygamy was discussed, one of the speakers, Maria Ulfah, a gender activist from Fatayat female NU organization, expressed her view, disapproving of the practice. Suddenly, one male judge of the court of Tangerang angrily stood up and declared his unwavering support for polygamy, arguing that, although the law restricts it, permission for polygamy is clearly stated in the Qu'ran. His female counterpart of the same court supported his view by offering a more elaborate and practical case. This female judge told the forum that she and her colleagues often had to deal with requests for polygamous marriages by husbands. In the hearings, wives often told the judges that they would have been, and were, badly treated by their husbands if they refused to give consent to their husbands. For this reason, this female judge assumed that if the husband's petition was not approved, he would have attacked his wife more violently. Concluding her point of view, the female judge stated that giving permission to a polygamous marriage would protect women or wives. This response invited fierce criticisms from other participants, gender activists in particular who considered the female judge's way of thinking had no ground as it was absurd and compounded the problems of domestic violence. ${ }^{61}$

It should be noted that in 2004 Indonesia issued a law on the elimination of violence against women (UU Penghapusan Kekerasan dalam Rumah Tangga). This Law, number 23 of 2004, thoroughly regulates the issue of domestic violence. According to this Law, domestic violence is categorized four ways: physical, mental, sexual, and by omission. On examining this provision, contending views emerge as to whether domestic violence has taken place in the case of husbands' polygamous marriage. On the one hand, from a perspective of Tangerang religious court female judges, a husband may have not committed physical violence on his wives should his proposal of polygamous marriage be approved by the religious court. On the other hand, according to Indonesian feminists, a husband has committed mental violence in polygamous

${ }^{61}$ Based on Nurlaelawati"s notes on the conference held at Niko Hotel, "On Access to Justice for Women," organized by Van Vollenhoven Institute (VVI) and Bappenas, 16 November 2010. 
marriage since it would result in misery in the wives' lives. Given this, the feminists insisted that the proposal of polygamous marriage should not be accepted because, although it avoids physical violence, it would facilitate a husband to commit another kind of domestic violence.

\section{E. Conclusion}

The presence of the female judges in Indonesia's religious courts has been a long and uneasy process. The engagement of women in Indonesia's Islamic judicial system started with a small number and then increased over time to include several important roles and positions in the religious court. Six decades ago, women acting as judges in Islamic courts did not exist in Indonesia, while in some other Muslim countries even nowadays the presence of female judges in the religious courts is still opposed. Given this, Indonesian women are more fortunate in having a right to access a profession in the Islamic court; in fact, all judicial positions under Indonesian legal system are not exclusively available to men.

Having key positions in the Indonesian religious judiciary system, female judges play a crucial gender role. They are expected not only to contribute time and energy with their male counterparts in upholding justice, but more particularly also to help defend the interest of poor and disadvantaged female litigants. In some cases discussed in this paper, female judges with strong gender awareness were more than able to understand what women or wives have had to undergo in family life and thus they enthusiastically handed down a decision that closely attends to women's best interests. This kind of gender awareness has its origin in internal and external sources. Some may have acquired it from their own intuitions or experiences as judges, who discover similar issues almost every week in their courtrooms. Others may not have conceived such awareness from within, but they subscribe to it because of their intense exposure to notions of gender equity through education and training.

However, there were some (female) judges with no gender sensitivity at all. Many factors could have contributed to this condition. One of them would be a prejudice that the problem with the women or wives originated with themselves and the resolution should come from their willingness to relent and concede. This lack of gender awareness 
is a serious challenge facing judges (male or female) that still persists in different courts (general or religious). This condition is exacerbated by the judge panel system, which applies throughout Indonesia's judicatures. Even (female) judges with strong awareness would not be able to aim for gender equity in their decision should other panel members prefer to stick to the letter of the law and oppose the idea of going beyond the text to achieve gender justice. 


\section{BIBLIOGRAPHY}

Bowen, John Richard, Islam, Law, and Equality in Indonesia: An Anthropology of Public Reasoning, Cambridge: Cambridge University Press, 2003.

----, "Shari'a, State and Social Norms in France and Indonesia," Institute for the Study of Islam in the Muslim World (ISIM) Lectures, Leiden: ISIM, 2001.

"Calon Hakim PA Harus Lebih Kuasai Hukum Acara", http://www.papandeglang.go.id/index.php/info-perkara/16-berita/info/50-calonhakim-pa-harus-lebih-kuasai-hukum-acara, accessed on Friday, 18 January 2013.

Cammack, Mark E., “The Indonesian Islamic Judiciary,” in Mark E. Cammack and Michael Feener (eds.), Islamic Law in Contemporary Indonesia: Ideas and Institutions, Harvard University Press, 2007.

Cammack, Mark. E., et.al, "Islamic Divorce Law and Practice in Indonesia," in R. Michael Feener and Mark E. Cammack (eds.), Islamic Law in Contemporary Indonesia, Cambridge: Harvard University Press, 2007.

Cammack, Mark. E. and Michael Feener, "The Islamic Legal System in Indonesia," Pacific Rim Law and Policy Journal, vol. 21, 1, 2012.

----, "Joint Marital Property in Indonesian Customary, Islamic, and National Law," in Peri Bearman, Wolfhart Heinrichs, Bernard G. Weiss (eds.), The Law applied: Contextualizing the Islamic Shari'a, a Volume in Honor of Frank E. Vogel, London: Tauris, 2008.

"Dua Srikandi PA Bengkalis Melanjutkan S-3," http://www.badilag.net/ berita-seputar-peradilan-agama/15231-dua-srikandi-pa-bengkalismelanjutkan-s-3--104.html, accessed on 10 April 2013.

Fattore, Christina, Thomas J. Scotto, and Arnita Sitasari, "Support for Women Officeholders in a Non-Arab Islamic Democracy: The Case of Indonesia," Australian Journal of Political Science, vol. 45, no. 2, June 2010 [DOI:10.1080/10361140903296586].

Hermansyah, "Hakim Perempuan di Peradilan Agama, Riwayatmu Kini," http://badilag.net/component/content/article/315-beritakegiatan/10712-hakim-perempuan-di-peradilan-agama-riwayatmu- 
kini-234.html, accessed on 23 April 2012.

----, "Profesor dan Doktor: Tujuh Hakim Lakukan Pembaharuan Hukum Islam," http://www.badilag.net/component/content/article/315berita-kegiatan/14983-professor-dan-doktor-tujuh-hakim-agunglakukan-pembaruan-hukum-islam-283.html, accessed on 28 March 2013.

Hirsch, Susan F., Pronouncing and Persevering: Gender and the Discourses of Disputing in an African Islamic Court, Chicago: University of Chicago Press, 1998.

Hooker, M.B., Islamic Law in South-East Asia, Kuala Lumpur: Oxford University Press, 1984.

Karni, Asrori S., "Prof. Ibrahim Hosen: Mujtahid Fatwa Bergelimang Pro dan Kontra," Gatra, 6 May 2009.

Lev, Daniel S., Islamic Court in Indonesia: A Study in the Political Bases of Legal Institution, Berkeley: University of California Press, 1972.

Lukito, Ratno, "Law and Politics in Post-Independence Indonesia: a Case Study of Religious and Adat Courts" in Arskal Salim and Azyumardi Azra (eds.), Sharia and Politics in Modern Indonesia, Singapore: ISEAS, 2003.

Moors, Annelies, Women and Property in Islam: Palestinian Experiences 19201990, Cambridge: Cambridge University Press, 1995.

Mujahidin, Ahmad, Peradilan Satu Atap di Indonesia, Jakarta: Refika Aditama, 2007.

"Muqoddas: Doktor Wanita Pertama Bidang Hukum Islam di UIN Sunan Gunung Djati Bandung," http://www.badilag.net/index.php/ pengaduan/315-berita-kegiatan/6107-sidang-terbuka-promosidoktor-atas-promovendus-hj-djazimah-muqoddas-219, accessed on 18 September 2010.

Muqaddas, Djazimah, Kontroversi Hakim Perempuan pada Peradilan Islam di Negara-negara Muslim, Yogyakarta: LKiS, 2011.

Nakamura, Hisako, Divorce in Java, Yogyakarta: Gadjah Mada University Press, 1983.

Nurlaelawati, Euis, "Indonesian Muslim Women at Court: Reform, Strategies and Pronouncement of Divorce," Journal of Islamic Law 
and Society, Leiden: Brill, 20: 3, 2013 [DOI: 10.1163/156851950010A0003].

----, “Shari'a-based Laws: The Legal Position of Women and Children in Indonesia," in Regime Change, Democracy, and Islam: The Case of Indonesia (A Final Report Islam Research Program), 2013, 38-39, http://media. leidenuniv.nl/legacy/irpfinal2013(2).pdf, accessed on 3 March, 2013.

----, Modernization, Tradition, and Identity: The Kompilasi Hukum Islam and Legal Practices of the Indonesian Religious Courts, Amsterdam: Amsterdam University Press, 2010.

Nurlaelawati, Euis, and Abdurrahman Rahim, "The Training, Appointment and Supervision of Islamic Judges in Indonesia," Pacific Rim Law and Policy Journal, Vol. 21, 1, 2012.

Peletz, Michael G., Islamic Modern: Religious Courts and Cultural Politics in Malaysia, Princeton: Princeton University Press, 2002.

Pitakasari, Ajeng Rizki, "Malaysia Tugaskan Hakim Wanita Pertama di Pengadilan Agama," http://www.republika.co.id/berita/duniaislam/islam-mancanegara/10/07/10/123981-malaysia-tugaskanhakim-wanita-pertama-di-pengadilan-syariah, accessed on July 9, 2010, accessed in June 25, 2013.

Pompe, Sebastian, The Indonesian Supreme Court: a Study of Institutional Collapse, Cornel: Cornel University, 2005.

Qudāma, Ibn, Al-Mughni, Egypt: Dār al-Manār, 1967.

Ruslan, Alia Hasna, "Peradilan Agama, Hakim Perempuan dan Penegakan Hukum Berkeadilan Gender," http://www.badilag.net/index. php?option $=$ com_content $\&$ task $=$ view\&id $=895 \&$ Itemid $=54$.

Salim, Arskal, Praktek Penyelesaian Formal dan Informal Masalab Pertanahan, Kewarisan dan Perwalian Pasca Tsunami di Banda Aceh dan Aceh Besar, Banda Aceh: IDLO, 2006.

Salim, Arskal et. al., Demi Keadilan dan Kesetaraan: Dokumentasi Program Sensitivitas Gender Hakim Agama, Jakarta: PUSKUMHAM UIN Jakarta, 2009.

Soetjipto, Any Widyani, "Big Party Politics: Still A Man's World?," A Report on Indonesia, http://library.fes.de/pdf-files/bueros/ philippinen/04527/08-indonesia.pdf. 
Starr, June, Law as Metaphor: from Islamic Courts to the Palace of Justice, New York: SUNY Press, 1992.

Sumner and Lindsey, Courting Reform: Indonesia's Islamic Courts and Justice for the Poor, New South Wales: Lowy Institute, 2010.

Tucker, Judith, In the House of the Law: Gender and Islamic Law in Syria and Palestine, 17th-18th Centuries, Berkeley: California University Press, 1998.

Taylor, Pamela K., "Malaysia Appoints First Female Sharia Judges," http://www.faithstreet.com/onfaith/2010/08/07/malaysiaappoints-first-female-sharia-judges/290, accessed on August 7 , 2010.

\section{Interviews}

Interview with one of the female judges in the Islamic court of Yogyakarta, July 2013.

Interviews with three respondents, HY and NF, July 2010, Jakarta, and AM, November, 2013, Yogyakarta. 